\title{
Pengukuran Penerimaan Sistem Informasi EWSKIA Berdasarkan Persepsi Pengguna dengan Menggunakan Technology Acceptance Model
}

\author{
Aris Puji Widodo ${ }^{a^{*}}$, Farid Agushybana ${ }^{\mathrm{b}}$, Sutopo Patria Jati ${ }^{\mathrm{c}}$ \\ ${ }^{a}$ Departemen Teknik Informatika FSM Universitas Diponegoro Semarang \\ b,c Departemen Kesehatan Masyarakat Universitas Diponegoro Semarang \\ Naskah Diterima : 2 Agustus 2018; Diterima Publikasi : 20 September 2018
}

DOI : 10.21456/vol8iss2pp166-173

\begin{abstract}
This study is a quantitative research that has a goal to measure the level of user acceptance of EWSKIA information system based on perception. EWSKIA is a healthcare application tool used to perform the process of recording and monitoring the health conditions of pregnant and childbirth mothers. The model used in this research is using Technology Acceptance Model (TAM) model with 3 variables, namely Perceived Ease of Use (PEOU), Perceived Usefulness (PU), and Behavioral Intention to Use (BITU). This variable consists of independent variables namely PEOU and PU, and the dependent variable is BITU. The respondents were 145 midwives from Grobogan District, Temanggung Regency and Salatiga City. Data analysis to conduct causal relationships between variables using Partial Least Square (PLS). The results of this study statistically show that the 3 hypotheses of $\mathrm{H} 1, \mathrm{H} 2$, and $\mathrm{H} 3$ adopted from the TAM model have a positive and significant influence. This is indicated by the value of the regression coefficient is positive and the coefficient of $\mathrm{P}$ value is less than 0.005 .
\end{abstract}

Keywords: Quantitative; EWSKIA; TAM; Acceptance; Ease of Use.

\begin{abstract}
Abstrak
Penelitian ini merupakan penelitian kuantitatif yang memiliki tujuan untuk melakukan pengukuran tingkat penerimaan pengguna terhadap sistem informasi EWSKIA berdasarkan persepsi. EWSKIA merupakan sebuah perangkat aplikasi bidang kesehatan yang digunakan untuk melakukan proses pencatatan dan pemantauan kondisi kesehatan ibu hamil dan melahirkan. Model yang digunakan pada penelitian ini menggunakan model Technology Acceptance Model (TAM) dengan 3 variabel, yaitu Perceived Ease of Use (PEOU), Perceived Usefulness (PU), dan Behavioral Intention to Use (BITU). Variabel ini terdiri dari variabel bebas yaitu PEOU dan PU, serta variabel terikat yaitu BITU. Responden yang digunakan adalah sebanyak 145 bidan yang berasal dari Kabupaten Grobogan, Kabupaten Temanggung, dan Kota Salatiga. Analisis data untuk melakukan hubungan kausal antar variabel menggunakan Partial Least Square (PLS). Hasil penelitian ini secara statistik menunjukan bahwa 3 hipotesis H1, H2, dan H3 yang diadopsi dari model TAM memiliki pengaruh positif dan signifikan. Hal ini ditunjukan dengan nilai koefisien regresi bernilai positif dan koefisien nilai P kurang dari 0.005 .
\end{abstract}

Kata kunci: Kuantitatif; EWSKIA; TAM; Penerimaan; Kemudahan dan Kemanfaatan.

\section{Pendahuluan}

Perkembangan teknologi informasi diberbagai sektor salah satu tujuannya adalah digunakan untuk mencapai tujuan organisasi secara efektif dan efisien. Dalam rangka memenuhi tercapainya tujuan tersebut, maka dibutuhkan sebuah sistem informasi yang merupakan representasi proses bisnis pada setiap aktivitas yang dimiliki oleh organisasi. Sistem informasi merupakan kombinasi dari teknologi informasi dan aktivitas manusia yang menggunakan teknologi untuk mendukung operasi dan manajemen organisasi (Beynon, 2009). Salah satu pemanfaatan sistem informasi adalah pada bidang kesehatan

\footnotetext{
*) Penulis korespondensi: arispw@gmail.com
}

khususnya untuk pelayanan kondisi kesehatan ibu hamil dan melahirkan. Kasus kematian ibu hamil di Indonesia masih cukup tinggi, yaitu sebesar 102 kematian per 100.000 kelahiran hidup (WHO, 2015). Salah satu penyebab tingginya angka kematian ibu hamil adalah disebabkan oleh lemahnya mekanisme pencatatan dan deteksi dini terhadap data kondisi kesehatan ibu hamil (Dharmawan., 2015). Upaya yang dapat dilakukan untuk menekan turunnya angka kematian ibu hamil, salah satu diantaranya dengan cara menyediakan instrumen yang dapat digunakan untuk proses pencatatan dan deteksi dini terhadap kondisi kesehatan ibu hamil. Instrumen diwujudkan dalam sebuah sebuah perangkat sistem informasi 
yang disebut dengan EWSKIA. EWSKIA merupakan sebuah perangkat aplikasi pada bidang kesehatan yang digunakan untuk melakukan proses pencatatan dan pemantauan kondisi kesehatan ibu hamil dan melahirkan. EWSKIA dikembangkan dengan menggunakan teknologi berbasis web yang dapat diakses oleh bidan desa dan pihak manajemen di lingkungan Puskesmas dan Dinas kesehatan kabupaten/kota. EWSKIA ini merupakan salah satu luaran dalam bentuk prototipe sebagai salah satu capaian yang dihasilkan pada skim Riset Pengembangan dan Penerapan (RPP) tahun 2017.

Sebelum dapat digunakan untuk operasional, EWSKIA sangat perlu untuk dilakukan pengukuran terhadap perilaku persepsi penerimaan pengguna. Pengukuran penerimaan pengguna bertujuan untuk mengetahui umpan balik dari pengguna, agar dapat digunakan sebagai perbaikan. Metode yang digunakan untuk melakukan pengukuran perilaku persepsi penerimaan pengguna terhadap EWSKIA adalah menggunakan pendekatan model TAM. Model TAM adalah merupakan salah satu model yang dibangun untuk menganalisis dan memahami faktor-faktor yang mempengaruhi diterimanya penggunaan teknologi komputer (Davis, 1986). Model TAM digunakan untuk melakukan pengukuran persepsi pengguna didasarkan pada instrumen-instrumen yang digunakan di model TAM adalah kuat, valid, dan reliabel (Malhotra, 1999).

Penelitian ini menggunakan kerangka model TAM yang dilakukan penyesuaian berdasarkan tujuan yang akan dicapai dengan memperhatikan perilaku dan persepsi pengguna EWSKIA. Adapun variabel yang digunakan difokuskan pada faktorfaktor kemudahan dan kemanfaatan EWSKIA oleh pengguna, dengan mengabaikan variabel atitute dan variabel eksternal.

\section{Kerangka Teori}

\subsection{Sistem Informasi EWSKIA}

Sistem informasi EWSKIA adalah merupakan sistem informasi yang digunakan untuk monitoring ibu hamil dan melahirkan dengan dilengkapi informasi peringatan dini terhadap kesehatan yang dialami ibu hamil dan melahirkan untuk membatu dalam pengambilan keputusan oleh petugas petugas kesehatan dalam memberikan tindakan baik berupa medis maupun non medis. Sistem informasi EWSKIA dikembangkan dengan menggunakan platform PHP Hypertext Prepocessor (PHP), database MySQL, dan teknik pemrogramannya menggunakan Model View Controller (MVC). Platform pengembangan sistem informasi EWSKIA menggunakan platform open source dengan pertimbangan agar tidak terbebani mengenai lisensi.

Adapun secara garis besar fungsionalitas utama yang dimiliki sistem informasi EWSKIA diantaranya meliputi sebagai berikut: Register data Wanita Usia
Subur (WUS) dan ibu hamil; Register data Kesehatan Ibu dan Anak (KIA) yang meliputi pemeriksaan ibu hamil, pemantauan tekanan darah terkini, akseptor Keluarga Berencana (KB), persalinan, kunjungan nifas dan kematian ibu; Laporan terkait Deteksi Risiko PE, Tabel Silang F. Risiko vs PE, Kohort Ibu, Ikhtisar Persalinan, Pelayanan KIA, Rekap PWS KIA, Laporan Risti Ibu Hamil dan Deteksi Dini Risiko Ibu Hamil. Beberapa tampilan sistem informasi EWSKIA diberikan pada Gambar1 dan 2.

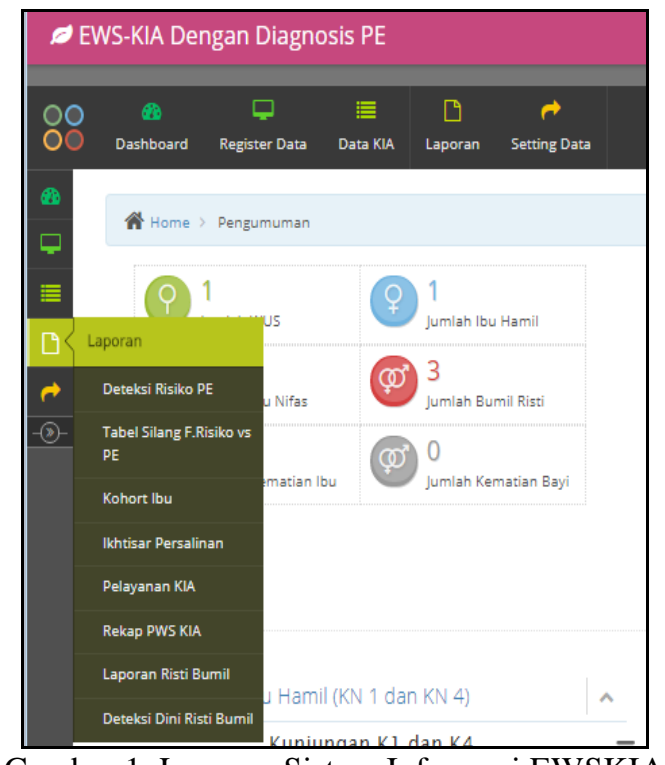

Gambar 1. Laporan Sistem Informasi EWSKIA

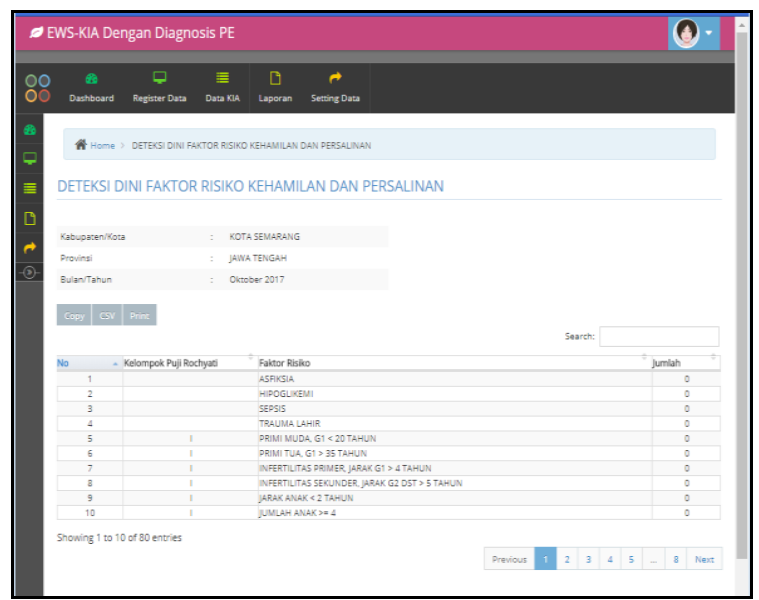

Gambar 2. Deteksi Dini Faktor Risiko Kehamilan dan Persalinan

\subsection{Model TAM}

Model TAM adalah salah satu model yang digunakan untuk menjelaskan keinginan pengguna dalam menggunakan sebuah sistem informasi (Davis, 1989). Tujuan model TAM menyediakan model konsep dasar secara teoritis dan kesederhanaan dalam hal mengenai penerimaan sebuah teknologi informasi untuk menjelaskan atau memprediksi terhadap adopsi sebuah teknologi (Davis, 1989). TAM menyediakan sebuah basis teori untuk mengetahui faktor-faktor 
yang mempengaruhi penermaan teknologi oleh pengguna pada sebuah organisasi. TAM menjelaskan hubungan sebab akibat antara keyakinan dan perilaku, tujuan dan pengguna aktual dari sistem informasi. Model TAM seperti yang diberikan pada Gambar 3. terdiri dari empat variabel, yaitu: Perceived Ease of Use (PEOU), Perceived Usefulness (PU), Attitude Toward Using (ATU), dan Behavioral Intention to Use (BITU). PEOU mampu meyakinkan pengguna bahwa sistem informasi yang akan digunakan bersifat mudah dan tidak menjadi beban. Sistem informasi yang mudah digunakan untuk terus dapat digunakan oleh pengguna. Persepsi kemudahan penggunaan mempengaruhi kegunaan, sikap, minat perilaku dan penggunaan (Sari dkk, 2012). Menurut Davis (1989) mendefinisikan PEOU sebagai suatu tingkatan kepercayaan seseorang terhadap penggunaan sistem informasi dapat mengurangi usaha seseorang dalam mengerjakan sesuatu. Intensitas penggunaan dan interaksi antara pengguna dengan sistem informasi dapat menunjukan kemudahan penggunaan. Sistem informasi yang sering digunakan menunjukan bahwa sistem informasi tersebut lebih mudah dioperasikan dan lebih mudah digunakan oleh pengguna. PU merupakan tingkatan keperyaan oleh pengguna terhadap sistem informasi untuk dapat meningkatkan prestasi kerja, sehingga dapat diartikan bahwa kemanfaatan penggunaan sebuah sistem informasi dapat meningkatkan kinerja, prestasi kerja orang yang menggunakannya. Menurut Thompson et. al (1991) menyimpulkan bahwa kemanfaatan teknologi informasi merupakan manfaat yang diharapkan oleh pengguna sistem informasi dalam melaksanakan pekerjaan. ATU merupakan sikap suka atau tidak suka terhadap penggunaan sebuah sistem informasi (Aakers dan Myers, 1997). Sikap suka atau tidak suka terhadap sistem informasi dapat digunakan untuk melakukan prediksi perilaku keingian pengguna dalam menggunakan atau tidak terhadap sebuah sistem inforamsi. ATU didefinisikan sebagai evaluasi dari pengguna mengenai tingkat ketertarikannya terhadap teknologi.

BITU adalah merupakan kecenderungan perilaku untuk tetap menggunakan sistem informasi (Davis, 1989). Tingkat penggunaan sebuah sistem informasi pada pengguna dapat dilakukan prediksi dari sikap perhatian pengguna terhadap sistem informasi tersebut, diantaranya keinginan menambah peripheral pendukung, motivasi untuk tetap menggunakan, serta keinginan untuk memotivasi pengguna lain.

Keempat variabel tersebut di atas memiliki determinan tinggi dan validitas yang teruji secara empirik menggunakan statistik untuk memprediksi deskripsi aspek-aspek perilaku pengguna sistem informasi (Chau, 1996). Pada penelitian ini, variabel eksternal diabaikan karena tidak memberikan pengaruh signifikan terhadap penerimaan penggunaan sistem informasi berdasarkan persepsi
(Santouridisa, 2014). Variabel ATU juga diabaikan, karena secara empirik ditemukan bahwa hubungan antara ATU dengan PEOU, PU, dan BITU sangat lemah (Suki, 2011).

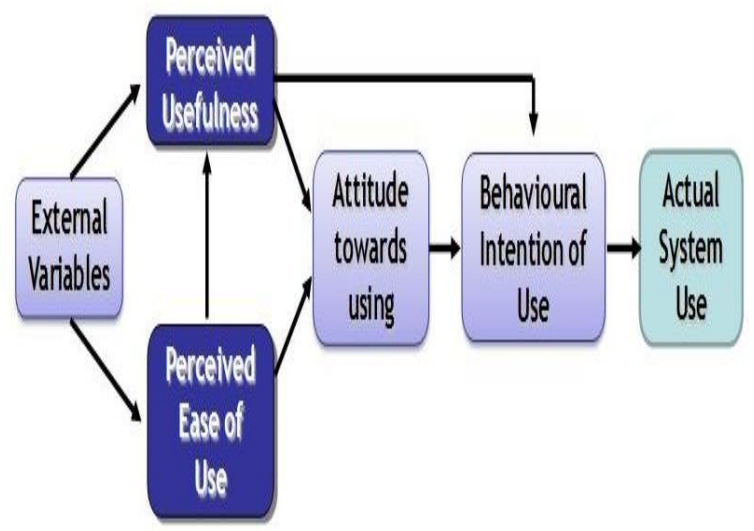

Gambar 3. Model TAM (Davis, 1989)

\subsection{Structure Equations Model (SEM)}

SEM merupakan suatu metodologi yang digunakan untuk merepresentasi, estimasi, dan menguji hubungan antar variabel yang teramati atau tidak (Rigdon, 1998). Definisi lainnya adalah sebagai berikut, SEM merupakan teknik analisis multivariat yang dikembangkan untuk mengurangi keterbatasan pada model-model analisis seperti analisis regresi, analisis jalur, dan analisis faktor konfirmatori (Hox dan Bechger, 1998). SEM merupakan salah satu analisis multivariat yang dapat digunakan untuk melakukan analisis hubungan antar variabel secara kompleks. SEM adalah teknik statistik yang kuat untuk menggabungkan model pengukuran dan model struktural menjadi uji statistik simultan (Thomson et al, 2013). Berdasarkan definisi diatas dapat diberikan kesimpulan bahwa SEM memiliki karakterisktik yang bersifat sebagai teknik analisis yang lebih ditekankan pada konfirmasi daripada menjelaskan variabel-variabel yang digunakan.

SEM memiliki tujuan untuk memahami pola hubungan dari sekumpulan variabel-variabel; untuk menjelaskan kemungkinan variasi hubungan antar variabel tersebut (Kline, 1998). Hubungan antar variabel yang dibangun antara satu atau beberapa variabel independent dengan satu atau beberapa variabel dependent. Setiap variabel dapat berbentuk sebuah konstruk yang dibangun dari beberapa indikator yang direncanakan dalam penelitian.

SEM memiliki keunggulan diantaranya adalah sebagai berikut: memberikan asumsi-asumsi yang lebih fleksibel, mengurangi kesalahan pengukuran dengan memiliki banyak indikator pada sebuah variabel, dan memberikan kemudahan dalam menginterprestasikan keluaran hasil analisis (Monecke, 2012). 


\subsection{Partial Least Square (PLS)}

PLS merupakan sebuah teknik statistik multivariat yang dapat digunakan untuk menyelesaikan banyak variabel respon dan variabel eksplanatori secara bersamaan. PLS merupakan alternatif yang baik untuk metode analisis regresi berganda dan regresi komponen utama, hal ini disebabkan karena PLS bersifat robust, yang dapat diartikan bahwa parameter model tidak banyak mengalami perubahan pada saat sampel baru ditentukan dari total populasi (Lowry dan Gaskin, 2014). PLS adalah merupakan sebuah teknik prediksi yang dapat digunakan untuk menyelesaikan banyak variabel independen (Sarstedt et al., 2014). PLS merupakan salah satu metode analisis yang baik karena dapat diterapkan untuk semua skala data yang tidak membutuhkan banyak asumsi dan ukuran sampel tidak harus besar. PLS dapat digunakan sebagai konfirmasi teori (theoritical testing) dan merekomendasikan hubungan yang belum memiliki dasar teorinya (eksploratori). PLS dapat juga digunakan untuk melakukan pemodelan structural dengan indiktor yang memiliki sifat formatif.

PLS memiliki tujuan untuk melakukan prediksi pengaruh variabel $\mathrm{X}$ terhadap $\mathrm{Y}$ dan menjelaskan hubungan teoritikal antara kedua variabel tersebut. PLS adalah metode regresi yang dapat digunakan untuk identifikasi faktor yang merupakan kombinasi variabel X sebagai penjelas dan variabel Y sebagai respon. Langkah-langkah menggunakan PLS meliputi sebagai berikut: (1) Merancang model struktural (Inner Model); (2) Merancang model pengukuran (Outer Model Formatif); (3) Melakukan evaluasi Goodness of fit inner model; dan (4) Melakukan pengujian hipotesis.

\subsection{Kajian Literatur}

Sistem informasi pada sebuah organisasi memiliki fungsi sebagai alat bantu untuk mencapai tujuan organisasi (Laudon, 2006). Keberhasilan sebuah sistem informasi tidak cukup ditentukan dari cara sistem dapat melakukan proses masukan dan menghasilkan sebuah informasi, akan tetapi dapat juga dipengaruhi oleh tingkat kesesuaian dengan lingkungannya. Lingkungan yang dimaksud adalah meliputi perangkat lunak, perangkat keras, dan pengguna sistem informasi. Lingkungan yang digunakan pada penelitian ini difokuskan pada pengguna sistem informasi. Untuk mengukur kesuksesan sistem informasi dapat dilakukan dengan cara melakukan pengukuran pada kepuasan pemakai, penggunaan sistem, kinerja keputusan, dan kinerja organisasi. Dalam penelitian ini kepuasan pemakai dan penggunaan sistem informasi digunakan untuk mengukur tingkat penerimaan pengguna sistem informasi.

Salah satu unsur penerapan sebuah sistem informasi adalah melakukan pengukuran tingkat penerimaan sistem informasi. Penerimaan terhadap sistem informasi dapat diukur dengan menggunakan beberapa model evaluasi. Model evaluasi yang digunakan untuk mengukur tingkat penerimaan sistem informasi diantaranya: Task Technology Fit, Human-Organization-Technology Fit (HOT Fit), dan Technology Acceptance Model (TAM) (Chau, 1996). Berdasarkan kajian dari sekian model yang dapat digunakan untuk mengukur tingkat penerimaan pengguna sistem informasi, maka, pada penelitian ini menggunakan model TAM yang digunakan untuk mengukur tingkat penerimaan sistem informasi EWSKIA.

Penelitian yang dilakukan oleh Priyanka (2014) menyatakan bahwa terdapat dua foktor penentu yang sangat penting dalam menggunakan teknologi informasi, yaitu persepsi mengenai PU dan PEOU yang mendefinisikan kepercayaan pengguna terhadap pengunaan teknologi adalah mudah dan tidak membutuhkan usaha lebih besar pada saat digunakan. Penelitian ini melakukan pengukuran hubungan antara variabel PU terhadap BITU, dan PEOU terhadap BITU.

Penelitian yang dilakukan oleh Wong (2015) menyatakan bahwa pengaruh PU memiliki efek langsung positif terhadap BITU, sehingga penelitian ini melakukan pengukuran hubungan antara variabel PU terhadap BITU.

Penelitian yang dilakukan oleh Supriyati dan Cholil (2017) menyatakan bahwa PU daan PEOU tidak memberikan pengaruh positif terhadap ATU, sehingga penelitian ini melakukan pengukuran hubungan antara variabel PU terhadap ATU dan PEOU terhadap ATU.

Berdasarkan telaan dari penelitian-penelitian sebelumnya, maka pada penelitian ini dilakukan pengukuran penerimaan berdasarkan persepsi pengguna sistem informasi EWSKIA yang difokuskan pada hubungan variabel PU terhadap BITU, variabel PEOU terhadap BITU, dan secara bersama-sama variabel PU dan PEOU terhadap BITU.

\section{Metode}

Penelitian ini adalah termasuk pada kategori penelitian kuantitatif dengan mengunakan rancangan penelitian kausal yang bertujuan untuk memperoleh hubungan sebab akibat antara variabel-variabel penelitian yang terdiri dari variabel PEOU, PU, dan BITU dalam hal untuk mengukur tingkat penerimaan pengguna sistem informasi EWSKIA berdasarkan persepsi. Metode yang digunakan adalah menggunakan model TAM yang telah dilakukan modifikasi sesuai dengan tujuan untuk mengukur penerimaan pengguna sistem informasi EWSKIA seperti yang diberikan pada Gambar 2. Variabel yang digunakan sebanyak 3 buah, yang dibagi menjadi 2 jenis, yaitu variabel bebas dan terikat. Variabel 
bebasnya adalah variabel PEOU dan PU, sedangkan variabel terikatnya adalah variabel BITU.

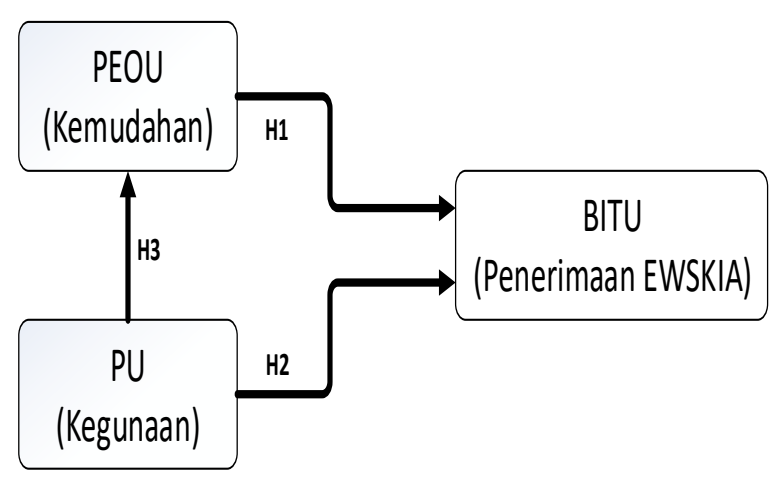

Gambar 4. Model Penelitian

Pada penelitian ini, untuk mengukur persepsi tingkat penerimaan pengguna terhadap sistem informasi EWSKIA menggunakan variabel PEOU, PU, dan BITU. Oleh karena itu beberapa hipotesis berdasarkan Gambar 4. yang dikembangkan pada penelitian ini adalah sebagai berikut:

1. Jika pengguna EWSKIA memiliki persepsi bahwa EWSKIA dengan mudah dapat dioperasikan dan mempermudah pekerjaannnya, maka pengguna semakin banyak menggunakan EWSKIA untuk menyelesaikan pekerjaannya, sehingga hipotesis yang dikembangkan adalah H1: variabel PEOU memiliki pengaruh positif terhadap penerimaan sistem informasi EWSKIA.

2. Jika pengguna EWSKIA memiliki persepsi bahwa EWSKIA bermanfaat untuk menyelesaikan pekerjaannya, maka pengguna semakin banyak menggunakan ESWKIA untuk menyelesaikan pekerjaannya, sehingga hipotesis yang dikembangkan adalah

H2: variabel PU memiliki pengaruh positif terhadap penerimaan sistem informasi EWSKIA.

3. Jika pengguna EWSKIA memiliki persepsi bahwa EWSKIA dengan mudah dapat dioperasikan dan bermanfaat untuk menyelesaikan pekerjaannnya, maka pengguna semakin banyak menggunakan EWSKIA untuk menyelesaikan pekerjaannya, sehingga hipotesis yang dikembangkan adalah

H3: Variabel PEOU dan PU secara bersamasama memiliki pengaruh positif terhadap penerimaan sistem informasi EWSKIA

Teknik pengambilan data pada penelitian ini menggunakan teknik survey dengan menggunakan kuisioner yang diberikan kepada responden sebanyak 145 bidan. Responden yang digunakan terdiri dari bidan yang berasal dari Kabupaten Grobogan, Kabupaten Temanggung, dan Kota Salatiga yang telah menggunakan sistem informasi ESWKIA. Skala yang digunakan pada penelitian ini menggunakan skala likert 5 point, terdiri dari: (1)
Sangat Tidak Setuju; (2) Tidak Setuju; (3) Netral; (4) Setuju; dan (5) Sangat Setuju.

Kuisioner yang telah diisi oleh bidan sebagai responden dan dikembalikan, kemudian selanjutnya dilakukan uji validitas dan reliabilitas. Uji validitas bertujuan untuk menguji setiap item-item pertanyaan adalah valid dan mencerminkan atribut yang diukur. Setiap item pertanyaan yang memiliki nilai loading factor > 0.5 adalah sebagai item valid (Ghozali, 2013). Uji reliabilitas terhadap item-item pertanyaan valid dengan menggunakan nilai alpha Cronbach. Nilai alpha $>0.70$ adalah termasuk reliabel (Nunnally, 1981). Setelah dilakukan uji validitas dan uji reliabitas, maka kemudian untuk selanjutnya dibuat analisis deskriptif yang menggambarkan hubungan antara variabel-variabel bebas dan terikat dengan menggunakan pendekatan PLS. PLS merupakan sebuah model persamaan SEM berbasis pada pendekatan komponen atau varian (Park, 2009). Tahap analisis data dengan menggunakan SEM dilakukan dengan menggunakan beberapa tahapan sebagai berikut: (1) melakukan uji validitas dan reliabilitas; (2) melakukan uji model hubungan antar variabel yang digunakan;, dan (3) melakukan konfirmasi model yang yang terbentuk.

\section{Hasil dan Pembahasan}

Pengumpulan data yang digunakan pada penelitian ini menggunakan teknik survei dengan kuisioner. Kuisioner yang dibuat untuk setiap variabel terdiri dari beberapa item-item pertanyaan sebagai berikut: PEOU sebanyak 3, PU sebanyak 3, dan BITU sebanyak 3. Adapun item pertanyaan yang digunakan pada kuisionernya adalah sebagai berikut PEOU (Kemudahan Dalam Berinteraksi, Kemudahan Dalam Penggunaan, Kenyamanan Tata Letak Secara Agronomis), PU (Meminimalkan Kesalahan, Kecepatan Dalam Menyelesaikan Pekerjaan, Memberikan Akurasi Data Tinggi), dan BITU (Berkeingian Lebih Sering Menggunakan Untuk Menyelesaikan Pekerjaan, Penyelesaian Pekerjaan Terbantu, Memiliki Kepercayaan Tinggi Dalam Menyelesaikan Pekerjaan).

Langkah selanjutnya berdasarkan model penelitian pada Gambar 2., dan hasil kuisioner yang telah diisikan oleh responden bidan dari ketiga kabupaten, kemudian dilakukan uji konfirmatori model secara keseluruhan untuk mengetahui Goodness of fit pada masing-masing variabel penelitian yang digunakan. Hasil uji konfirmatori model disajikan seperti yang diberikan pada Gambar 5., yang dilengkapi dengan nilai loading factor, koefisien alpha Cronbach, koefisien nilai regresi, dan koefisien nilai $\mathrm{P}$. 


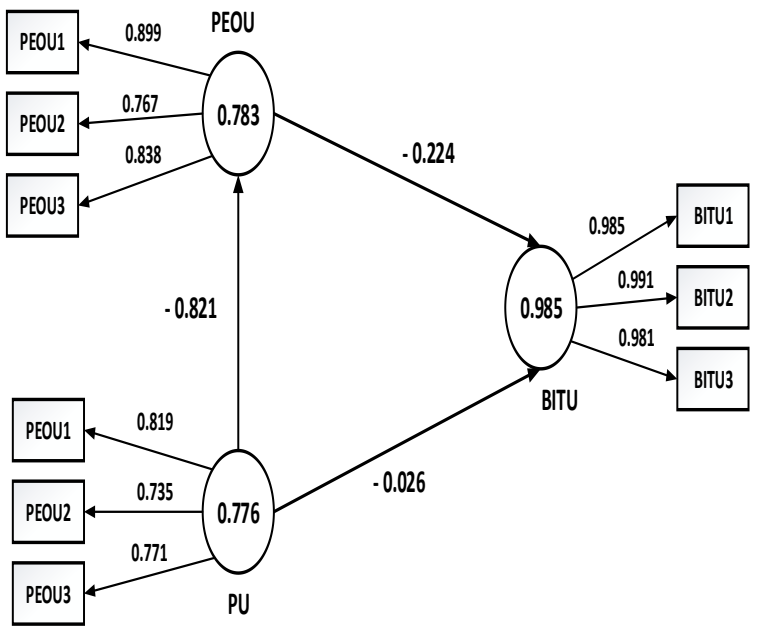

Gambar 5. Uji Konfirmatori Model

Tabel 1. Uji Validitas

\begin{tabular}{cccc}
\hline Variabel & Item & Loading Factor & Keterangan \\
\hline PEOU & PEOU1 & 0.899 & Valid \\
& PEOU 2 & 0.767 & Valid \\
& PEOU 3 & 0.838 & Valid \\
PU & PU1 & 0.819 & Valid \\
& PU2 & 0.735 & Valid \\
& PU3 & 0.771 & Valid \\
BITU & BITU1 & 0.985 & Valid \\
& BITU2 & 0.991 & Valid \\
& BITU3 & 0.981 & Valid \\
\hline
\end{tabular}

Uji validitas dilakukan dengan cara menghitung nilai loading factor untuk setiap item pertanyaan. Nilai loading factor dinyatakan valid jika nilainya di atas 0.5 , sedangkan jika nilai loading factornya kurang dari sama dengan 0.5 dinyatakan tidak valid. Hasil uji validitas pada Tabel 1, menunjukan bahwa semua item-item pertanyaan memiliki nilai loading factor lebih besar dari 0.5, sehingga dapat disimpulkan bahwa untuk setiap item-item pertanyaan tersebut dapat dinyatakan sebagai item pertanyaan valid. Uji reliabilitas dilakukan dengan menghitung nilai alpha Cronbach terdahap variabel PEOU, PU, dan BITU. Nilai alpha Cronbach dinyatakan reliabel jika nilainya di atas 0.70 , sedangkan jika nilai alpha Cronbach kurang dari sama dengan 0.70 dinyatakan tidak reliabel. Hasil uji reliabilitas diberikan pada Tabel 2, menunjukan bahwa nilai alpha Cronbach untuk setiap variabel di atas nilai 0.70 , sehingga dapat dinyatakan bahwa setiap variabel adalah bersifat reliabel.

Tabel 2. Uji Reliabilitas

\begin{tabular}{lcc}
\hline \multicolumn{1}{c}{ Variabel } & Alpha Cronbach & Keterangan \\
\hline PEOU & 0.783 & Reliabel \\
PU & 0.776 & Reliabel \\
BITU & 0.985 & Reliabel \\
\hline
\end{tabular}

Analisis data dilakukan dengan cara membuat model baru. Model baru yang dibuat menggunakan acuan dari hasil uji validitas dan uji reliabilitas, yaitu dilakukan dengan cara menghapus item-item pertanyaan yang tidak valid. Pada penelitian ini semua item pertanyaan dinyatakan valid, sehingga tidak ada item pertanyaan yang dihapus. Selanjutnya dari model baru dilakukan uji signifikasi dengan cara dengan cara menghapus nilai variabel yang tidak signifikan, dan selanjutnya dilakukan hubungan kausal antar variabel. Hubungan kausal dilakukan dengan menggunakan pendekatan PLS.

Hubungan kausal $\mathrm{H} 1$ diterima jika nilai $\mathrm{P}$ kurang dari 0.005 dan koefisien regresinya positif, sedangkan $\mathrm{H} 1$ ditolak jika nilai $\mathrm{P}$ lebih besar sama dengan 0.005 atau koefisien regresinya negatif. Hasil uji signifikansi antara variabel PEOU terhadap BITU, PU terhadap BITU, PEOU dan PU terhadap BITU diberikan pada Tabel 3. Berdasarkan hasil uji signifikansi yang diberikan pada Tabel 3., menunjukan bahwa semua nilai koefisien regresinya memiliki nilai positif, dan semua nilai P negatif (nilai P kurang dari 0.005), oleh karena itu secara statistik dapat diberikan kesimpulan bahwa semua hipotesis $\mathrm{H} 1, \mathrm{H} 2$, dan $\mathrm{H} 3$ dapat diterima.

Tabel 3. Uji Signifikansi

\begin{tabular}{lcc}
\hline \multicolumn{1}{c}{ Kausal } & Koefisien Regresi & $\mathrm{P}$ \\
\hline PEOU $\rightarrow$ BITU & 0.341 & -0.224 \\
PU $\rightarrow$ BITU & 0.552 & -0.026 \\
PEOU, PU $\rightarrow$ BITU & 0.447 & -0.821 \\
\hline
\end{tabular}

Konsekuensi dari hipotesis $\mathrm{H} 1$ diterima adalah jika pengguna EWSKIA memiliki persepsi bahwa EWSKIA mudah dioperasikan, maka pengguna dapat menerima EWSKIA secara lebih mudah untuk menyelesaikan pekerjaannya. Oleh karena itu berdasarkan hasil penelitian ini, bahwa dalam pengembangan sistem informasi sudah seharusnya mempertimbangkan aspek-aspek kemudahan penggunaan agar pengguna lebih mudah menerima sistem informasi tersebut. Konsekuensi dari hipotesis $\mathrm{H} 2$ diterima adalah jika pengguna EWSKIA memiliki persepsi bahwa EWSKIA memiliki manfaat dalam menyelesaikan pekerjaannya, maka pengguna dapat menerima EWSKIA yang dimanfaatkan untuk menyelesaikan pekerjaannya. Oleh karena itu berdasarkan hasil penelitian ini bahwa dalam pengembangan sistem informasi seharusnya dapat mengakomodasi kebutuhan pengguna berdasarkan aktivitas proses bisnis pengguna. Konsekuensi dari hipotesis $\mathrm{H} 3$ diterima adalah jika pengguna EWSKIA memiliki persepsi bahwa EWSKIA mudah dioperasikan dan memiliki manfaat untuk menyelesaikan pekerjaanya, maka pengguna lebih mudah menerima EWSKIA sebagai bagian dari kewajiban menjalankan pekerjaanya. Oleh karena itu berdasarkan hasil penelitian ini bahwa dalam 
pengembangan sistem informasi seharusnya dapat mengakomodasi kebutuhan pengguna sesuai dengan aktivitas proses bisnis yang diberlakukan pada setiap organisasi, kemudian juga perlu dipertimbangkan aspek-aspek kemudahan bagi pengguna untuk mengoperasikan sistem informasi tersebut.

\section{Kesimpulan}

Penerimaan sistem informasi EWSKIA oleh bidan di Kabupaten Grobogan, Kabupeten Temanggung, dan Kota Salatiga dipengaruhi oleh persepsi bidan terhadap kemudahan penggunan (PEOU) dan kemanfaatan (PU) untuk menyelesaikan pekerjaannya. Oleh karena itu bidan akan lebih mudah menerima sistem informasi EWSKIA, jika bidan memiliki keyakinan bahwa sistem informasi EWSKIA mudah dioperasikan dan memberikan manfaat untuk menyelesaikan pekerjaanya.

\section{Ucapan Terima Kasih}

Terima kasih kepada Lembaga Penelitian dan Pengabdian Kepada Masyarakat (LPPM) Universitas Diponegoro Semarang yang telah memberikan dukungan sepenuhnya dan pemberian sumber dana dalam pelaksanaan kegiatan penelitian pada skim Riset Pengembangan dan Penerapan (RPP) tahun anggaran 2017.

\section{Daftar Pustaka}

Beynon,D., P., 2009. Management Information Systems. 10th edition, Palgrave, Basingstoke.

Chau, P., Y., K., 1996. Measurement Scales for Perceived Usefulness and Perceived Ease of Use.

Davis, M., 1986. A Technology of Acceptance Model for Empirically testing new-end user information system: Theory and Result. Massachusetts, USA: Sloan School of Management, Massachusets Institute of Technology.

Dharmawan, Y., Wigati, P.,A., Dwijayanti, F., 2015. Kinerja petugas dalam pencatatan dan pelaporan PWS KIA di puskesmas duren. Jurnal Kesehatan Masyarakat. Jurnal Kesehaatan Masyarakat, Volume 10 (2), 210-217.

Hox J., Bechger T., 1998. An introduction to structural equation modeling. Family Science Rewiew, 11:354-373.

Ghozali, I., 2006. Structural Equation Modeling, Metode Alternatif dan Partial Least Square. Edisi 2. Semarang: Badan Penerbit Universitas Diponegoro.

Ghozali, I., 2013. Model Persamaan Struktural Konsep dan Aplikasi Dengan Program Amos 21.0, Cetakan Kelima, Badan Penerbit Universitas Diponegoro.
Laudon, K., C., 2006. Management Information Systems. Edisi 8. New Jersey: Prentice- Hall, Inc.

Lowry, P., B., and Gaskin, J., 2014. Partial Least Squares (PLS) Structural Equation Modeling (SEM) for Building and Testing Behavioral Causal Theory: When to Choose It and How to Use It. IEEE Transactions on Professional Communication, Volume: 57, Issue: 2, 123 - 146.

Malhotra, Y., Galetta, D., F., 1999. Extending The Technology Acceptance Model to Account for Social Influence

Monecke, A., Leisch, F., 2012. SEM PLS: Structural equation modeling using partial least square. Journal of Statistic Software.

Nunnally, J., C., 1981. Psycometric Theory, 2nd ed., Tata McGraw-Hill Publishing Company Limited, New Delhi.

Park, S., Y., 2009. An analysis of the Technology Acceptance Model in Understanding University Students Behavioral Intention to Use e-Learning. Educational Technology and Society 12 (3): 150162.

Priyanka, S., Kumar, M., A., 2014. A study on Adoption of E-Reccrukment Using Technology Acceptance Model (TAM) with reference to graduating students in iniversitiesin Bahrain. International Journal of Advance Research in Computer Scienceand Management Studies.Vol,2, Issue 9, 2321-7782.

Rigdon, E., E., 1998. Structural equation modeling. In Modern methods for business research, G. A. Marcoulides (editor). Mahwah, NJ: Lawrence Erlbaum Associates, Publishers.

Santouridisa, I., Kyritsib, M. 2014. Investigating the Determinants of Internet Banking Adoption in Greece. Procedia Economics and Finance.

Sari, M., W., dan Baridwan. Z., 2012. Sikap penggunaan mobile commerce: modifikasi teori technology acceptance model. Jurnal Ilmiah Mahasiswa Fakultas Ekononomi Universitas Brawijaya.

Sarstedt, M., Ringle, C.M., Smith, D., Reams, R., 2014. Partial least squares structural equation modeling (PLS-SEM): A useful tool for family business researchers. Journal of Family Business Strategy, Volume 5, Issue 1, 105-115.

Suki, N., M., 2011. Exploring the relationship between perceived usefulness, perceived ease of use, perceived enjoyment, attitude and subscribers' intention towards using $3 \mathrm{G}$ mobile services. Journal of Information Technology Management, Vol. XXII, No. 1, 1-7.

Supriyati, Cholil, M. 2017. Aplikasi technology acceptance model pada sistem informasi manajemen rumah sakit. Jurnal Bisnis \& Manajemen, 17 (1), 81 - 102.

Thompson, R., L, Christopher A. Higgins, C. A., Howell, J. M., 2013. Influence of EYperience on Personal Computer Utilization: Testing A 
Conceptual Model, Journal of Management Information sistems

Wager, K.A., Lee, W. F., Glaser \& P.J., 2009. Health Care Information Systems: A Practical Approach For Health Care Management. Second edition, Addison Wiley.
WHO, 2015. Countdown to 2015, Health Metrics Network (HMN), Uni Monitoring maternal, newborn and child health: understanding key progress indicators.

Wong, G., K., W., 2015. Understanding technology acceptance in pre-service teachers of primary mathematics in Hong Kong. Australasian Journal of AducationalTechnology, Volume 31, Nomor 6, pp 108-120. 